\title{
Polychlorinated dibenzo- $p$-dioxins/furans and polychlorinated biphenyls in sediments and aquatic organisms from the Taihu Lake, China
}

\author{
Qinghua Zhang, Guibin Jiang *
}

State Key Laboratory of Environmental Chemistry and Ecotoxicology, Research Center for Eco-Environmental Sciences, Chinese Academy of Sciences, P.O. Box 2871, Beijing 100085, People's Republic of China

Received 1 October 2004; received in revised form 31 January 2005; accepted 24 February 2005

Available online 4 May 2005

\begin{abstract}
Sediments at 16 sites and muscles of four aquatic species collected in Taihu Lake were analyzed for polychlorinated dibenzo- $p$-dioxins, dibenzofurans (PCDD/Fs) and polychlorinated biphenyls (PCBs) by HRGC/HRMS. The concentrations of total PCDD/Fs, PCBs and WHO-TEQ were 120.1-1315.1 pg/g dw, 889.7-29747.8 pg/g dw, and 0.83$17.72 \mathrm{pg} \mathrm{TEQ} / \mathrm{g} \mathrm{dw}$, respectively in sediments; and those in muscles were $5.49-35.84 \mathrm{pg} / \mathrm{g} \mathrm{ww}, 1517.10-27647.98$ $\mathrm{pg} / \mathrm{g} \mathrm{ww}$, and $0.52-3.83 \mathrm{pg}$ TEQ/g ww respectively. The concentrations of PCDD/Fs and PCBs in the sediments were decreasing gradually along the water flow. The pollution levels were compared with other studies and the possible sources were discussed.
\end{abstract}

(c) 2005 Elsevier Ltd. All rights reserved.

Keywords: Taihu Lake; PCDD/Fs; PCBs; Sediment; Aquatic organism

\section{Introduction}

Taihu Lake, located in eastern China, is the third largest freshwater lake in China. As one of the most developed regions, the Taihu basin plays a critical role in the national economic development. The lake is very important due to its multiple functions: water supply, sightseeing, fishery and shipping route. One-third of the drinking water of Wuxi city is supplied from Meiliang Bay, a sublake of Taihu Lake. With the rapid development of economy and explosion of city population in recent decades, the lake has been seriously polluted by

\footnotetext{
* Corresponding author. Tel.: +86 10 62849334/62923566; fax: +861062923563 .

E-mail address: gbjiang@mail.rcees.ac.cn (G. Jiang).
}

domestic and industrial effluent. Now the lake is heavily eutrophicated and the quality of the water is deteriorating. Serious blue-green algae water blooms have been frequently occurring in recent years (Zhang and Qin, 2001a). The pollutants in Taihu Lake include nitrogen, phosphorus, heavy metals, some persistent organic pollutants, such as DDT and $\mathrm{HCH}$ (Zou et al., 1996; Dai and Sun, 2001; Zhang and Qu, 2001b; Yuan et al., 2002; Wang et al., 2003; Feng et al., 2003). However, study on PCDD/Fs and PCBs in the lake is scarce. To protect the source of drinking water in the Meiliang Bay, a project using ecological principles was carried out in 2003 to improve water quality. As a part of the project, the concentration levels of PCDD/Fs and PCBs in sediments and some aquatic organisms of the lake were investigated. 


\section{Materials and methods}

\subsection{Chemical reagents and standard solutions}

All solvents were pesticide residue grade and were purchased from Fisher (Fair Lawn, NJ, USA). Silica gel was obtained from Merck (silica gel 60, Darmstadt, Germany). Acid alumina was purchased from Aldrich (Brockmann I, standard grade, Milwaukee, USA). Florisil was obtained from Riedel-de Haën (60-100 mesh ASTM, Seelze, Germany). Calibration standard solutions, ${ }^{13} \mathrm{C}$-labeled surrogate standards and injection standards complying with EPA method 1613B and certified reference material of fish (EDF-2526) for dioxin analysis were obtained from Cambridge Isotopes Laboratories (Andover, MA, USA). Standards complying with EPA method 1668A for PCBs analysis were obtained from Weillington Laboratories (Guelph, Canada).

\subsection{Sampling area}

The sampling locations are in the area targeted by the cleanup project. Ten sampling sites are roughly around the Chongshan waterworks in Meiliang Bay, a sublake situated in the north east of Taihu Lake (Fig. 1). The region of the project is also marked in the figure. Surface sediments (about $5 \mathrm{~cm}$ in depth) were collected with a grab sediment sampler in September, 2002. One sediment core of about $30 \mathrm{~cm}$ long was collected at site A3 by a core sampler supplied by Nanjing Institute of Geography and Limnology, Chinese Academy of Sciences. The core was separated into four equal parts. Normally, the water in Taihu Lake flows from the north to the south. The other six sampling sites were selected along the flow. Aquatic organisms including common carp (Parabramis pekinensis), crucian carp (Carassius auratus), catfish (Parasilurus asotus) and fresh water mussel (Cyelina sinensis) were collected in site A and site B6 (the name is labeled with " $\mathrm{A}$ " or " $\mathrm{B}$ " which corresponds to the site). The weight of the fishes ranged from $0.5 \mathrm{~kg}$ to $1 \mathrm{~kg}$. All of the samples were kept frozen at $-20{ }^{\circ} \mathrm{C}$ until analysis.

\subsection{Sample preparation}

The sediment samples were freeze-dried in the laboratory. The fish muscle with skin was homogenized and then was freeze-dried. ${ }^{13} \mathrm{C}$-labeled surrogate standards were spiked according to the EPA method 1613B and 1668A. Soxhlet extraction was carried out for $1-2 \mathrm{~g}$ dry sediment and $2 \mathrm{~g}$ dry muscle for $24 \mathrm{~h}$. The solvents were toluene for sediment and 50\% dichloromethane in hexane for muscle, respectively. After determining the lipid content, the muscle extract was adjusted to $50 \mathrm{ml}$ with hexane and $15 \mathrm{~g}$ of acid silica $(30 \% \mathrm{w} / \mathrm{w})$ was added

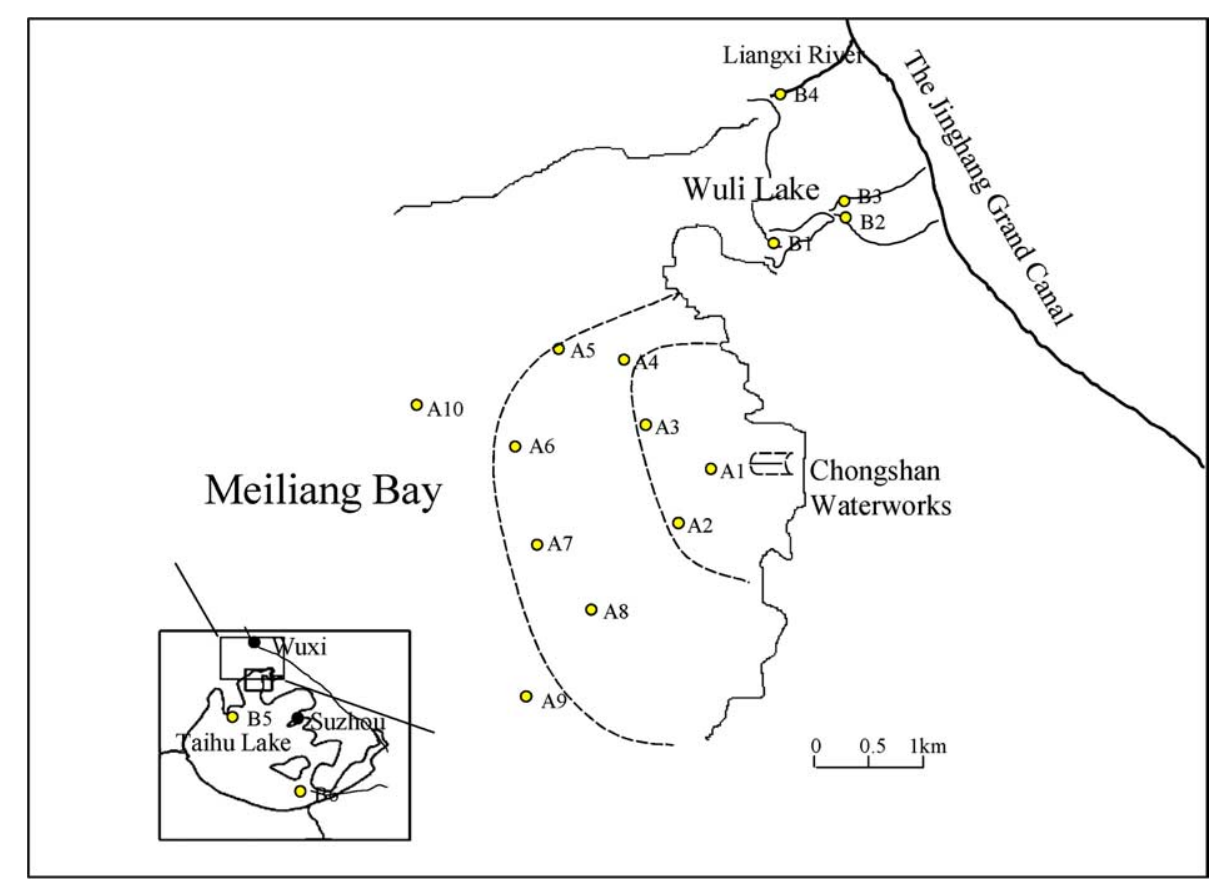

Fig. 1. Map of Taihu Lake and location of sampling sites. 
to remove lipid. The acid silica was stirred for $2 \mathrm{~h}$ and the extract was poured through approximately $5 \mathrm{~g}$ of anhydrous sodium sulfate. All of the extracts were concentrated to about $2 \mathrm{ml}$ by rotary evaporator for the following cleanup.

\subsection{Sample purification}

The extract was sequentially subjected to multilayered silica gel, acid alumina and florisil chromatographic columns for cleanup. The multi-layered silica gel column was packed from bottom to top with $1 \mathrm{~g}$ actived silica, $4 \mathrm{~g}$ basic silica $(1.2 \% \mathrm{w} / \mathrm{w}), 1 \mathrm{~g}$ actived silica, $8 \mathrm{~g}$ acid silica $(30 \% \mathrm{w} / \mathrm{w}), 1 \mathrm{~g}$ actived silica, $2 \mathrm{~g}$ $\mathrm{AgNO}_{3}$ silica $(10 \% \mathrm{w} / \mathrm{w})$ and topped with $4 \mathrm{~g}$ anhydrous sodium sulfate. The column was pre-washed by $100 \mathrm{ml}$ hexane before use. The eluate was loaded onto the column and eluted by $150 \mathrm{ml} \mathrm{5 \%}$ dichloromethane in hexane. Then the extract was concentrated to about $2 \mathrm{ml}$ and eluted by $40 \mathrm{ml}$ dichloromethane:hexane $(1: 1, \mathrm{v} / \mathrm{v})$ through $6 \mathrm{~g}$ actived acid alumina. PCBs fraction was eluted from $1 \mathrm{~g}$ actived Florisil by $30 \mathrm{ml} \mathrm{5 \%}$ dichloromethane in hexane and then PCDD/Fs fraction was eluted by $40 \mathrm{ml}$ dichloromethane. Afterwards, the extracts were concentrated with gentle nitrogen flow and the solvent was changed to $10 \mu \mathrm{l}$ nonane in a minivial. Before instrumental analysis, ${ }^{13} \mathrm{C}$-labeled injection standards were added and the vial was vortexed to mix completely.

\subsection{Instrumental analysis}

The quantification of PCDD/F and PCB homologues was performed by HRGC/HRMS on a Agilent 6890 gas chromatography coupled with an Autospec Ultima mass spectrometer (Waters Micromass, Manchester, UK) operating in the EI mode at $35 \mathrm{eV}$ and the trap current was $600 \mu \mathrm{A}$. The details of the MS analysis and quality control are described in the EPA method 1613B and 1668A. The GC was equipped with a CTC PAL autosampler. One or two microlitre sample was injected in splitless mode (splitless time, $2 \mathrm{~min}$ for PCDD/Fs and 1 min for PCBs respectively) in a DB-5MS fused silica capillary column $(60 \mathrm{~m} \times 250 \mu \mathrm{m}$ i.d. $\times 0.25 \mu \mathrm{m}$ film thickness) with helium as carrier gas at a constant flow rate of $1.2 \mathrm{ml} / \mathrm{min}$. The oven temperature programs were as follows: for PCDD/Fs: start $160^{\circ} \mathrm{C}$ held for $2 \mathrm{~min}$, $160-220^{\circ} \mathrm{C}$ at $7.5^{\circ} \mathrm{C} / \mathrm{min}$ held for $16 \mathrm{~min}, 220-235^{\circ} \mathrm{C}$ at $5{ }^{\circ} \mathrm{C} / \mathrm{min}$ held for $7 \mathrm{~min}, 235-330^{\circ} \mathrm{C}$ at $5{ }^{\circ} \mathrm{C} / \mathrm{min}$ held for $1 \mathrm{~min}$; for PCBs: start $80^{\circ} \mathrm{C}$ held for $2 \mathrm{~min}, 80$ $150{ }^{\circ} \mathrm{C}$ at $15^{\circ} \mathrm{C} / \mathrm{min}, 150-270{ }^{\circ} \mathrm{C}$ at $2.5^{\circ} \mathrm{C} / \mathrm{min}$ held for $3 \mathrm{~min}, 270-330^{\circ} \mathrm{C}$ at $15^{\circ} \mathrm{C} / \mathrm{min}$ held for $1 \mathrm{~min}$.

\subsection{Quality control}

All of the samples were spiked with labeled compounds to monitor method performance. A method blank with each sample batch (12 samples) was checked. One certified reference material of fish was also ana-

Table 1

Recovery of PCBs and PCDD/Fs in sediments $(n=10)$ and certified reference material (EDF-2526) of fish and concentrations of background contamination of PCBs in method blanks $(n=4)$

\begin{tabular}{|c|c|c|c|c|c|c|c|c|c|c|}
\hline \multirow[t]{2}{*}{ Compounds } & \multirow{2}{*}{$\begin{array}{l}\text { Recovery } \\
{ }^{13} \mathrm{C}_{12}(\%)\end{array}$} & \multirow[t]{2}{*}{$\mathrm{SD}$} & \multirow{2}{*}{$\begin{array}{l}\text { Background } \\
\text { mean }(\mathrm{pg} / \mathrm{g})\end{array}$} & \multirow{2}{*}{$\begin{array}{l}\mathrm{SD} \\
(\mathrm{pg} / \mathrm{g})\end{array}$} & \multirow{2}{*}{$\begin{array}{l}\text { LOD } \\
(\mathrm{pg} / \mathrm{g})\end{array}$} & \multirow[t]{2}{*}{ Compounds } & \multirow{2}{*}{$\begin{array}{l}\text { Recovery } \\
{ }^{13} \mathrm{C}_{12}(\%)\end{array}$} & \multirow[t]{2}{*}{$\mathrm{SD}$} & \multicolumn{2}{|l|}{ EDF-2526 } \\
\hline & & & & & & & & & $\begin{array}{l}\text { Certified } \\
\text { value }(\mathrm{pg} / \mathrm{g})\end{array}$ & $\begin{array}{l}\text { This study } \\
(\mathrm{pg} / \mathrm{g})\end{array}$ \\
\hline PCB-77 & $66(47-86)$ & 12 & 0.6 & 0.54 & 0.2 & 2378-TCDF & $79(53-98)$ & 15 & $17 \pm 1.5$ & 22.9 \\
\hline PCB-81 & $62(47-81)$ & 12 & 0.2 & 0.02 & 0.2 & 12378-PeCDF & $70(48-91)$ & 16 & $40 \pm 3.7$ & 48.9 \\
\hline PCB-105 & $76(61-92)$ & 12 & 1.1 & 0.89 & 0.2 & 23478-PeCDF & $114(60-162)$ & 34 & $38 \pm 3.5$ & 40.9 \\
\hline PCB-114 & $54(42-63)$ & 7 & $\mathrm{nd}^{\mathrm{a}}$ & 0.05 & 0.2 & 123478-HxCDF & $65(28-87)$ & 23 & $80 \pm 8.4$ & 87.3 \\
\hline PCB-118 & $59(51-82)$ & 11 & 2.8 & 1.91 & 0.2 & 123678-HxCDF & $65(30-87)$ & 20 & $63 \pm 5.5$ & 64.4 \\
\hline PCB-123 & $65(52-78)$ & 10 & 0.3 & 0.38 & 0.2 & 234678-HxCDF & $71(46-87)$ & 13 & $60 \pm 5.5$ & 54.5 \\
\hline PCB-126 & $69(53-86)$ & 13 & nd & 0.05 & 0.2 & 123789-HxCDF & $77(51-91)$ & 13 & $58 \pm 7.0$ & 64.6 \\
\hline PCB-156 & $69(53-87)$ & 12 & 0.4 & 0.25 & 0.2 & 1234678-HpCDF & $62(32-77)$ & 17 & $83 \pm 9.2$ & 96.7 \\
\hline PCB-157 & $55(43-63)$ & 7 & nd & 0.06 & 0.2 & 1234789-HpCDF & $77(54-93)$ & 13 & $73 \pm 7.7$ & 79.4 \\
\hline PCB-167 & $53(42-62)$ & 7 & 0.3 & 0.09 & 0.2 & OCDF & & & $190 \pm 22$ & 148.3 \\
\hline PCB-169 & $51(40-59)$ & 7 & nd & 0.06 & 0.2 & 2378-TCDD & $85(55-101)$ & 14 & $19 \pm 1.4$ & 20.2 \\
\hline PCB-189 & $33(28-41)$ & 4 & nd & 0.07 & 0.2 & 12378-PeCDD & $95(59-126)$ & 26 & $40 \pm 3.0$ & 41.0 \\
\hline PCB-28 & & & 20.4 & 9.69 & 0.5 & 123478-HxCDD & $70(34-95)$ & 21 & $60 \pm 4.8$ & 56.6 \\
\hline PCB-52 & & & 6.4 & 2.33 & 0.2 & 123678-HxCDD & $63(38-86)$ & 18 & $56 \pm 4.8$ & 59.0 \\
\hline PCB-101 & & & 8.0 & 4.04 & 0.5 & 123789-HxCDD & & & $60 \pm 4.4$ & 63.1 \\
\hline PCB-138 & & & 4.4 & 3.19 & 0.2 & 1234678-HpCDD & $91(60-108)$ & 17 & $76 \pm 5.9$ & 69.1 \\
\hline PCB-153 & & & 5.6 & 4.34 & 0.2 & OCDD & $58(37-74)$ & 12 & $192 \pm 14$ & 192.0 \\
\hline PCB-180 & & & 0.4 & 0.30 & 0.1 & & & & & \\
\hline PCB-209 & & & 1.1 & 0.15 & 0.1 & & & & & \\
\hline
\end{tabular}

\footnotetext{
${ }^{\mathrm{a}}$ nd $=$ not detected.
} 
Table 2

PCDD/Fs and PCBs in sediments and muscle of aquatic organisms ${ }^{\mathrm{a}}$ from Taihu Lake (pg/g dw for sediment and pg/g ww for muscle) ${ }^{\mathrm{b}}$

\begin{tabular}{|c|c|c|c|c|c|c|c|c|c|c|c|c|c|c|}
\hline \multirow[t]{2}{*}{ Compounds } & \multicolumn{2}{|c|}{$A^{\mathrm{c}}(n=10)$} & \multirow[t]{2}{*}{ B1 } & \multirow[t]{2}{*}{ B2 } & \multirow[t]{2}{*}{ B3 } & \multirow[t]{2}{*}{ B4 } & \multirow[t]{2}{*}{ B5 } & \multirow[t]{2}{*}{ B6 } & \multirow{2}{*}{$\begin{array}{l}\text { Common } \\
\text { carp A1 }\end{array}$} & \multirow{2}{*}{$\begin{array}{l}\text { Common } \\
\text { carp A2 }\end{array}$} & \multirow{2}{*}{$\begin{array}{l}\text { Crucian } \\
\text { carp A }\end{array}$} & \multirow[t]{2}{*}{ Catfish A } & \multirow{2}{*}{$\begin{array}{l}\text { Freshwater } \\
\text { mussel A }\end{array}$} & \multirow{2}{*}{$\begin{array}{l}\text { Common } \\
\text { carp B3 }\end{array}$} \\
\hline & Mean & Range & & & & & & & & & & & & \\
\hline 2378-TCDF & 1.9 & $0.8-\mathbf{2 . 6}$ & 0.8 & 14.1 & 3.1 & 3.8 & 0.9 & 0.5 & 0.12 & 0.14 & 0.78 & 1.83 & 0.63 & 0.90 \\
\hline 12378-PeCDF & 1.4 & $0.7-2.3$ & 1.0 & 13.0 & 1.7 & 0.8 & 1.0 & 0.8 & 0.08 & 0.12 & 0.24 & 0.75 & 0.13 & 0.27 \\
\hline 23478-PeCDF & 1.1 & $0.4-2.4$ & 0.5 & 9.4 & 2.2 & 0.6 & 0.9 & 1.1 & 0.15 & 0.15 & 0.56 & 1.03 & 0.23 & 0.60 \\
\hline 123478-HxCDF & 2.2 & $0.8-\mathbf{5 . 0}$ & 1.0 & 25.2 & 3.3 & 1.9 & 1.0 & 1.3 & 0.06 & 0.1 & 0.09 & 0.15 & 0.07 & 0.12 \\
\hline 123678-HxCDF & 1.6 & $0.7-2.6$ & 0.6 & 12.9 & 1.8 & 0.9 & 0.7 & 0.9 & 0.03 & 0.06 & 0.08 & 0.15 & 0.05 & 0.1 \\
\hline 234678-HxCDF & 1.3 & $0.5-\mathbf{2 . 7}$ & 1.3 & 14.6 & 2.0 & 1.4 & 1.1 & 1.0 & 0.04 & 0.04 & 0.06 & 0.14 & 0.08 & 0.1 \\
\hline 123789-HxCDF & 0.4 & $0.2-0.7$ & 0.4 & 1.9 & 0.1 & 0.4 & 0.2 & 0.2 & 0.02 & 0.04 & 0.02 & 0.03 & 0.02 & 0.03 \\
\hline 1234678-HpCDF & 6.8 & $4.0-11.0$ & 7.2 & 78.1 & 10.4 & 6.9 & 4.1 & 4.6 & 0.05 & 0.43 & 0.18 & 0.37 & 0.26 & 0.07 \\
\hline 1234789-HpCDF & 0.8 & $0.2-2.9$ & 0.2 & 13.1 & 1.5 & 0.8 & 0.3 & 0.6 & 0.02 & 0.08 & $\mathbf{0 . 0 3}$ & 0.04 & 0.02 & 0.03 \\
\hline OCDF & 9.7 & $6.3-13.7$ & 24.1 & 241.0 & 39.6 & 33.4 & 5.3 & 11.1 & 0.02 & 1.51 & 0.64 & 1.41 & 0.79 & 0.01 \\
\hline 2378-TCDD & 0.5 & $0.2-\mathbf{1 . 0}$ & 0.6 & 0.5 & 0.2 & 0.5 & 0.3 & 0.4 & 0.09 & 0.12 & 0.11 & 0.19 & 0.05 & 0.08 \\
\hline 12378-PeCDD & 0.8 & $0.2-\mathbf{2 . 0}$ & 0.6 & 1.4 & 0.3 & 0.6 & 0.2 & 0.4 & 1.05 & 0.78 & 0.16 & 0.3 & 0.05 & 0.21 \\
\hline 123478-HxCDD & 1.0 & $0.3-\mathbf{3 . 0}$ & 0.3 & 1.6 & 0.5 & 0.8 & 0.2 & 0.5 & 0.18 & 0.27 & 0.09 & 0.11 & 0.02 & 0.08 \\
\hline 123678-HxCDD & 0.9 & $0.3-\mathbf{1 . 4}$ & 0.3 & 3.7 & 1.1 & 0.8 & 0.6 & 0.3 & 0.14 & 0.19 & 0.07 & 0.14 & 0.02 & 0.08 \\
\hline 123789-HxCDD & 1.7 & $0.3-\mathbf{4 . 0}$ & 0.3 & 2.3 & 0.7 & 0.4 & 0.7 & 0.3 & 0.04 & 0.03 & 0.03 & 0.05 & 0.02 & 0.03 \\
\hline 1234678-HpCDD & 11.5 & $6.6-25.3$ & 7.1 & 32.1 & 10.4 & 5.5 & 4.8 & 5.2 & 0.18 & 0.4 & 0.16 & 0.31 & 0.19 & 0.19 \\
\hline OCDD & 111.2 & $77.2-203.3$ & 121.3 & 231.8 & 110.1 & 81.4 & 49.8 & 53.6 & 0.87 & 3.15 & 1.28 & 3.32 & 1.66 & 0.47 \\
\hline PCB-77 & 30.4 & $21.1-48.6$ & 28.1 & 190.8 & 52.9 & 55.5 & 8.1 & 3.7 & 8.94 & 5.18 & 19.99 & 54.86 & 15.56 & 12.5 \\
\hline PCB-81 & 1.4 & $0.6-3.3$ & 2.0 & 2.6 & 1.8 & 1.1 & 0.5 & 0.2 & 1.05 & 0.39 & 1.16 & 6.97 & 0.71 & 1.28 \\
\hline PCB-105 & 34.7 & $24.5-57.9$ & 42.3 & 162.6 & 57.8 & 68.7 & 10.6 & 6.8 & 27.22 & 25.75 & 106.51 & 360.32 & 27.67 & 33.62 \\
\hline PCB-114 & 4.0 & $1.1-7.7$ & 7.2 & 9.4 & 2.8 & 3.9 & 1.3 & 0.3 & 4.08 & 1.06 & 6.01 & 22.65 & 1.15 & 1.85 \\
\hline PCB-118 & 83.6 & $59.4-143.9$ & 107.9 & 529.0 & 138.9 & 210.2 & 25.7 & 17.7 & 84.69 & 92.79 & 357.8 & 1000.94 & 75.5 & 98.07 \\
\hline PCB-123 & 15.1 & $9.4-23.0$ & 23.0 & 36.5 & 15.3 & 18.7 & 3.8 & 0.4 & 3.22 & 4.33 & 16.87 & 93.9 & 4.99 & 3.56 \\
\hline PCB-126 & 2.8 & $1.9-4.1$ & 3.4 & 13.3 & 5.0 & 4.8 & 1.4 & 0.5 & 1.41 & 1.15 & 5.43 & 22.56 & 1.89 & 2.35 \\
\hline PCB-156 & 9.7 & $6.8-17.7$ & 12.3 & 47.6 & 12.7 & 20.3 & 3.4 & 2.0 & 9.92 & 7.82 & 41.14 & 80.99 & 8.32 & 13 \\
\hline PCB-157 & 3.1 & $2.2-4.3$ & 4.7 & 22.9 & 8.8 & 10.4 & 1.2 & 0.6 & 3.27 & 2.37 & 10.74 & 47.05 & 3.31 & 3.73 \\
\hline PCB-167 & 4.5 & $3.0-8.1$ & 7.7 & 41.4 & 16.6 & 17.5 & 1.2 & 1.1 & 5.78 & 7.50 & 30.8 & 89.94 & 6.46 & 6.98 \\
\hline PCB-169 & 0.5 & $0.2-0.9$ & 0.6 & 4.9 & 1.6 & 1.6 & 0.3 & 0.3 & 0.25 & 0.14 & 1.05 & 3.20 & 0.32 & 0.67 \\
\hline PCB-189 & 1.2 & $0.8-1.6$ & 1.4 & 8.3 & 2.4 & 3.3 & 0.5 & 0.4 & 1.28 & 0.73 & 5.18 & 11.39 & 1.16 & 2.24 \\
\hline PCB-28 & 255.0 & $147.4-394.8$ & 375.9 & 3601.9 & 1280.2 & 1174.5 & 62.5 & 14.9 & 32.83 & 92.00 & 142.76 & 1371.05 & 113.59 & 163.86 \\
\hline PCB-52 & 53.5 & $27.4-124.5$ & 72.8 & 513.0 & 174.3 & 234.2 & 11.9 & 10.4 & 11.66 & 25.94 & 45.02 & 521.61 & 32.68 & 55.09 \\
\hline PCB-101 & 78.6 & $36.3-131.7$ & 104.8 & 747.8 & 228.3 & 320.6 & 15.2 & 20.8 & 67.09 & 95.47 & 210.77 & 1622.87 & 103.76 & 85.59 \\
\hline PCB-138 & 81.9 & $49.5-142.4$ & 108.5 & 429.5 & 172.6 & 207.6 & 22.7 & 19.1 & 132.52 & 83.92 & 473.17 & 1109.89 & 97.62 & 153.36 \\
\hline
\end{tabular}




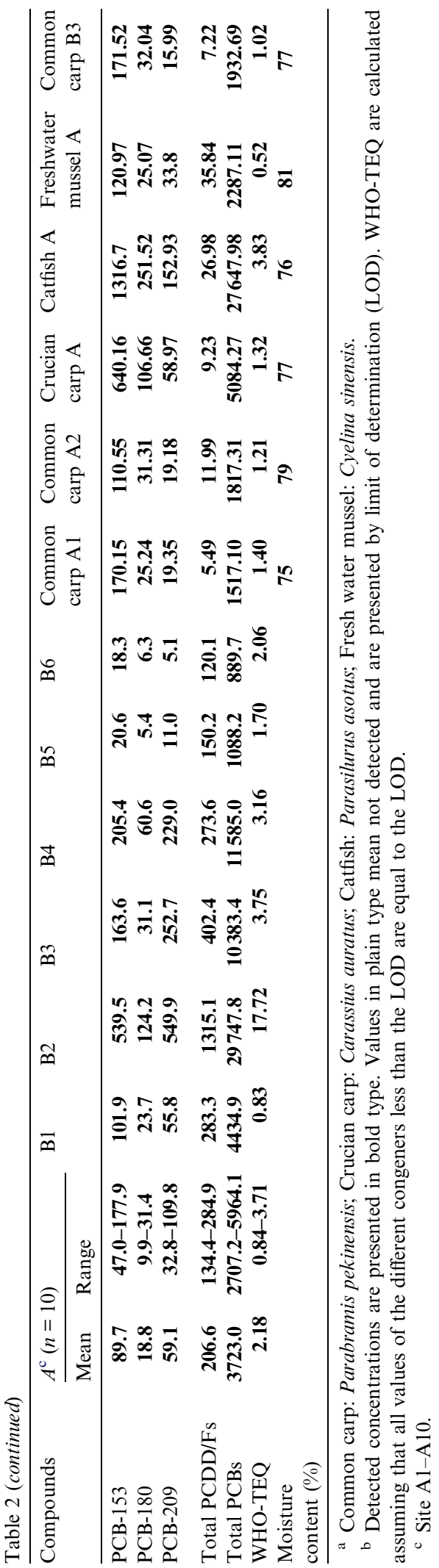

lyzed. The recovery of each labeled compound met the limits of the USEPA methods and the concentrations determined for the 17 congeners of PCDD/Fs were in excellent agreement with the EDF-2526 reference fish certified values (Table 1). We also participated in an international intercalibration study in 2002 (Van Bavel, 2003). The results demonstrated that the performance of our method was quite acceptable for analysis of toxic congeners of $\mathrm{PCDD} / \mathrm{Fs}$ and PCBs.

\section{Results}

\subsection{Blanks control and detection limits}

For dioxin analysis, method blanks indicated freedom from contamination except negligible OCDD or OCDF. But for PCBs, several WHO toxic congeners and all of the indicator congeners could be detected if the chromatography materials were not cleaned up. The significant background levels for some PCB congeners have been reported in several studies (Aries et al., 2004). Contamination in silica gel was the main source for this pollution and we baked the silica gel at $600{ }^{\circ} \mathrm{C}$ overnight to eliminate the contamination. The level of background contamination after the treatment was presented in Table 1. Since the background concentrations are significantly lower than the amount of most samples $(<10 \%)$, the blank contamination could be neglected. Limit of detection (LOD, $S / N=3$ ) of each target congener of our method was shown in the results if the congener was not detected. Generally, the LOD of $2,3,7,8-\mathrm{TCDD}$ was $0.5 \mathrm{pg} / \mathrm{g} \mathrm{dw}$ for sediment sample and $0.07 \mathrm{pg} / \mathrm{g}$ ww for tissue sample. For PCBs, the LOD would be lower (about $0.2 \mathrm{pg} / \mathrm{g} \mathrm{dw}$ for PCB 126 for sediment sample). It was not necessary to extract more amount of sample because this sensitivity was generally satisfactory for investigation or risk assessment.

\subsection{PCDD/Fs and PCBs in the sediments}

Seventeen 2,3,7,8-substituted chlorinated congeners of PCDD/Fs, 12 WHO toxic congeners of PCBs, six indicator PCBs (PCB 28, 52, 101, 138, 153 and 180) and PCB 209 were quantitatively determined. Toxicity equivalency (TEQ) was calculated based on the WHOTEFs for humans/mammals (Van den Berg et al., 1998). Total PCDD/Fs and total PCBs were calculated using total area of all the peaks detected in respective functions. The levels of PCDD/Fs and PCBs in sediments and biota samples are shown in Table 2.

The concentrations of total PCDD/Fs and total PCBs in the surface sediments ranged from 120.1$1315.1 \mathrm{pg} / \mathrm{g} \mathrm{dw}$ to $889.7-29747.8 \mathrm{pg} / \mathrm{g} \mathrm{dw}$, respectively. Site B2 was the most heavily polluted area for both PCDD/Fs and PCBs. For PCDD/Fs, OCDD is the most 

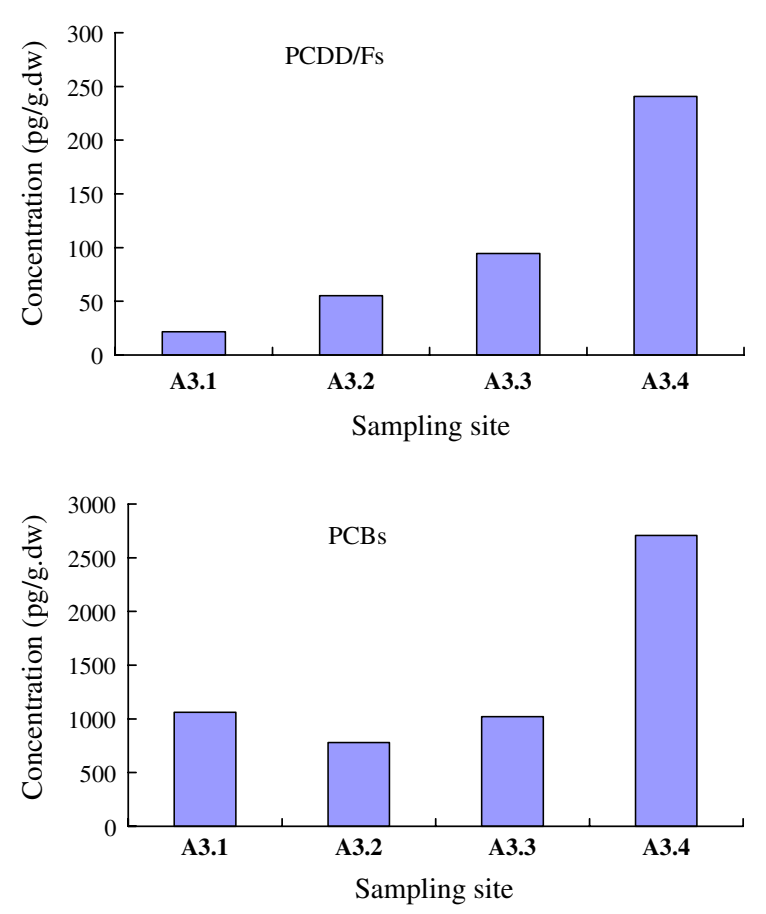

Fig. 2. Total PCDD/Fs and PCBs in sections of sediment core (pg/g dw) (A3.1-A3.4: bottom to top layer of sediment core sampled at site A3). abundant congener, followed by OCDF and HpCDD. Compared with PCDD/Fs, the levels of PCBs are higher and all of the target congeners can be detected. Among WHO toxic congeners, PCB 118 was the highest one and the concentration varied from 59.4 to $143.9 \mathrm{pg} / \mathrm{g} \mathrm{dw}$. PCB 105 and PCB 77 could be detected at $20-60 \mathrm{pg} /$ $\mathrm{gdw}$. The most toxic PCB 126 is very low. The result of indicator PCBs shows that PCB 28 is the most abundant congener and the other indicator congeners are at the similar level, mostly between 50 and $100 \mathrm{pg} / \mathrm{g} \mathrm{dw}$. PCB 209 was detected at around $50 \mathrm{pg} / \mathrm{g} \mathrm{dw}$ level. The total WHO-TEQ varied between 0.83 and 17.72 $\mathrm{pg} / \mathrm{g} \mathrm{dw}$.

The results of the sediment core indicated increasing trend from the bottom to top (Fig. 2). For PCBs, the trend is not so in gradient as that in PCDD/Fs. The concentrations in three bottom layers are at the same level but in the top layer the concentrations rise significantly. This is a general pattern for PCBs in sediment cores of many locations of China (Chen et al., 1999).

\subsection{PCDD/Fs and PCBs in the aquatic organisms}

PCDD/Fs and PCBs in the muscle of four species were determined. The concentrations of total PCDD/ Fs and total PCBs ranged from $5.49-35.84 \mathrm{pg} / \mathrm{g}$ ww to $1517.10-27647.98 \mathrm{pg} / \mathrm{g}$ ww, respectively. The total WHO-TEQ varied between 0.52 and $3.83 \mathrm{pg} / \mathrm{g}$ ww. The WHO-TEQ of catfish was obviously the highest. The

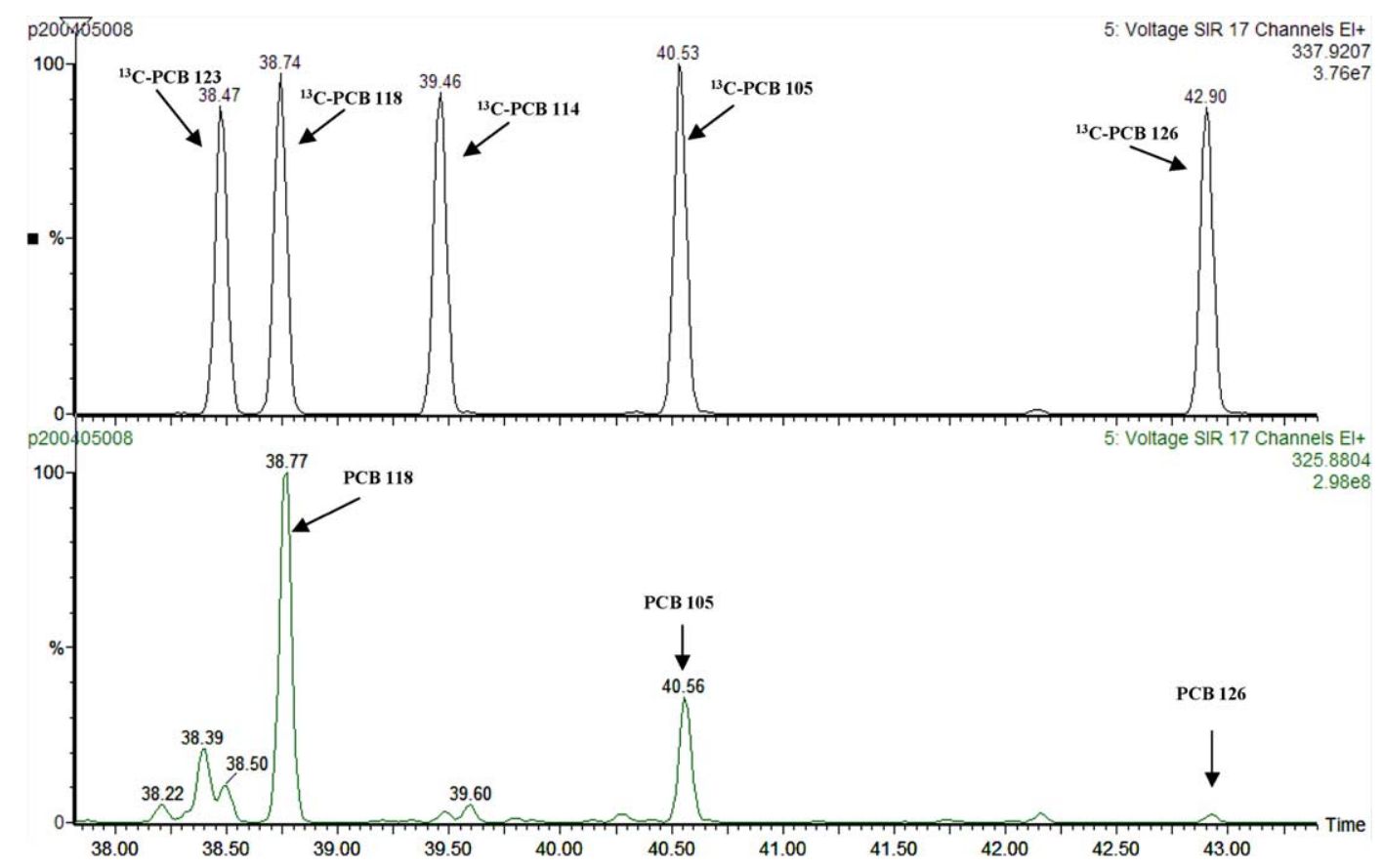

Fig. 3. Mass chromatography of selected PCBs in the muscle of catfish. 
total PCBs of catfish was almost 10 times higher than that of the other biota samples. Although OCDD and OCDF were the dominant congeners of PCDD/Fs, the ratio of tetra or penta chlorinated congeners was higher compared with that in sediments. $2,3,7,8-\mathrm{TCDF}$ in catfish was $1.83 \mathrm{pg} / \mathrm{g}$ ww and 1,2,3,7,8-PeCDD in a common carp was $1.05 \mathrm{pg} / \mathrm{g}$ ww. PCB 118 was the highest among the WHO toxic congeners and the concentration varied from 75.5 to $1000.94 \mathrm{pg} / \mathrm{g} \mathrm{ww}$, followed by PCB 105 and 77. Fig. 3 shows that PCB 118 and 105 could be detected at considerable levels in the muscle of catfish. The fingerprint of indicator PCBs in biota samples was quite different from that in sediments. PCB 153, 101, 138 and 28 were at similar level. Furthermore, the weight of total WHO toxic congeners in total PCBs became higher obviously. Co-planar PCBs accounted for $70 \%$ and $50 \%$ of total TEQ in catfish and crucian carp, respectively, whereas that distribution in sediments was quite low, which accounted for no more than $20 \%$ except for that in the site B1. But the distribution of co-planar PCBs of total TEQ was lower in common carp. The difference indicated the different bioaccumulation behavior of PCDD/Fs and PCBs between species.
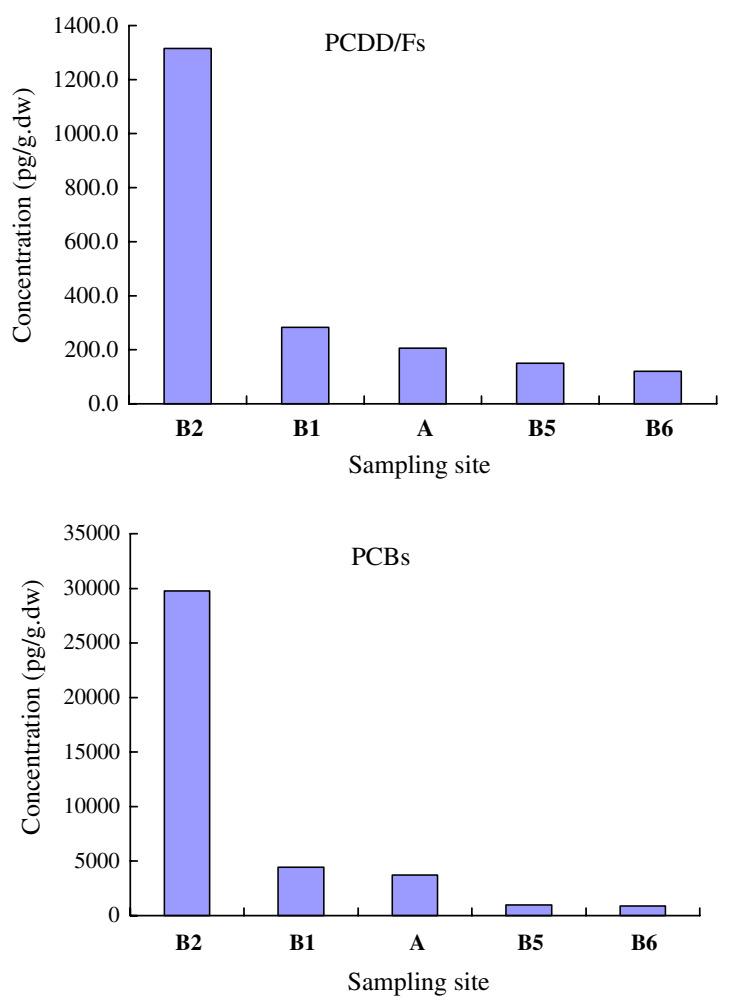

Fig. 4. Total PCDD/Fs and $\mathrm{PCBs}$ in sediments along the effluent.

\section{Discussion}

\subsection{Pollution level and risk assessment of PCDD/Fs and PCBs in Taihu Lake}

Compared to several other locations in China, the levels of PCDD/F and PCBs in sediments of Taihu Lake are quite low except for the sites of three canals connected to the lake where the pollution status of PCBs was at average level (10.5-20.5 ng/g; Chen et al., 1999). The level of PCBs was also significantly lower than the ERL recommended by Long et al. (22.7 ng/g; 1995). So PCDD/F and PCBs in sediments of Taihu Lake pose not serious risk for the environmental health.

The target congeners of PCBs in muscle of aquatic organisms could be detected at a rate of $100 \%$. The level of the WHO-TEQ of PCBs was similar to that in Japanese aquatic organisms investigated in 1999 (2.1 pg TEQ/ww; Japanese EPA, 1999). The concentra-
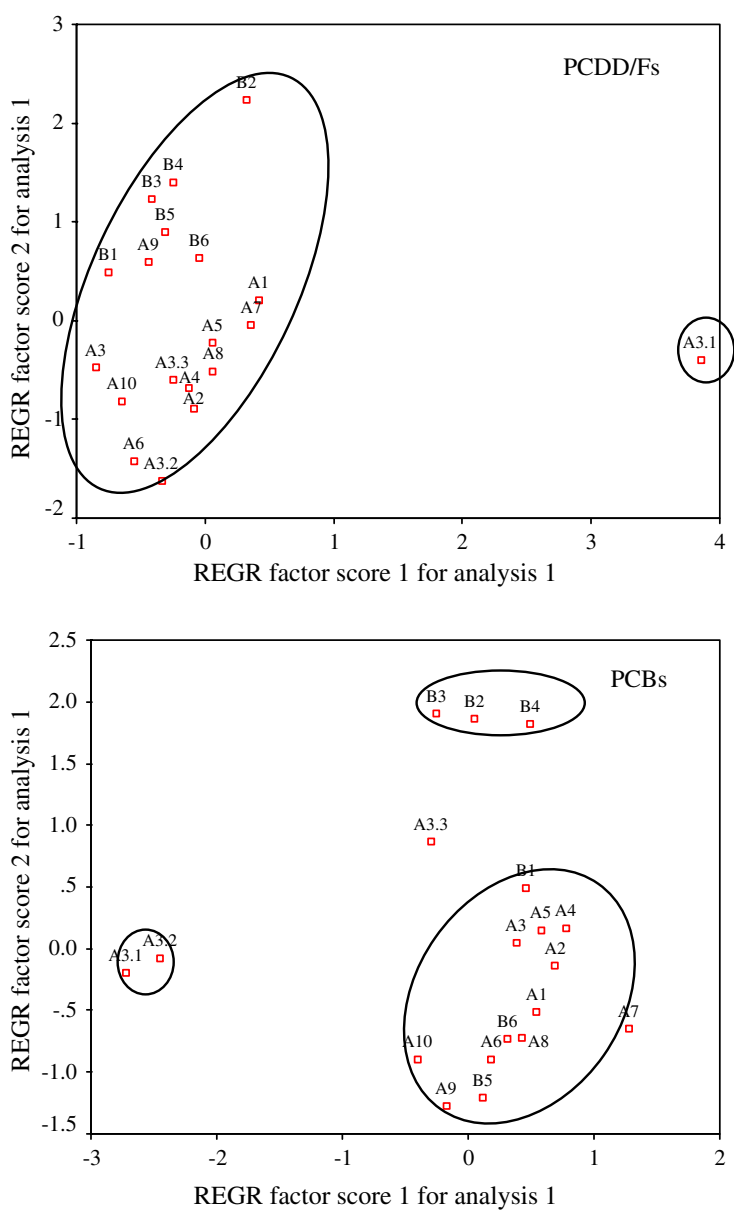

Fig. 5. The score plot from the principal component analysis of normalized PCDD/Fs and PCBs data in sediments of Taihu Lake. 
tions were also lower than the European Union regulation limit $(4.0 \mathrm{pg} / \mathrm{g} w \mathrm{w})$. WHO recommended a TDI of $1-4 \mathrm{pg} / \mathrm{kg}$ bw. In some areas around Taihu Lake, fish is the primary protein source in the diet of resident and the average consumption of fish is more than $100 \mathrm{~g} /$ day. So PCDD/Fs and PCBs in the aquatic organisms have potential health risk for the resident if they eat too much fish, especially the fish with higher content of lipid such as catfish.

\subsection{Possible sources}

Municipal wastewater from Wuxi city flows into Taihu Lake through some canals and the water in the lake mainly runs out through Taipuhe River at the site B6. The flow direction is: $\mathrm{B} 2, \mathrm{~B} 3, \mathrm{~B} 4 \rightarrow \mathrm{A} \rightarrow \mathrm{B} 5 \rightarrow \mathrm{B} 6$. The concentration of PCDD/Fs and PCBs in sediments was decreasing gradually along the water flow (Fig. 4). The profile suggested that the wastewater was a very important source of PCDD/Fs and PCBs in Taihu Lake.

PCA was performed in order to find out the differences and similarities in PCDD/Fs and PCBs profiles among different sites. For PCDD/Fs, 25 variables of the relative concentrations of 17 2,3,7,8-substituted chlorinated and respective total tetra to octa chlorinated congeners were defined as a data set. Corresponding relative concentrations of six indicator PCBs were defined as variables for PCBs. The values of the first two factor variables are plotted (factor score plot) (Fig. 5). It is clearly that the congener profiles of PCDD/Fs and PCBs in surface sediments of the lake area were similar. The profile in the bottom sediment of the sediment core was different from that of the surface sediment. The result indicated that the pollutants input had been historically changed. The congener profile of PCBs in sediments of three canals was slightly different from that of surface sediments in lake area, suggesting that other pollution sources of PCBs existed. Some latest studies showed that atmospheric transport and deposition could be a major input of PCBs or other persistent organic pollutants to Taihu Lake (Qiu et al., 2004; Yuan et al., 2004). In all sediments, OCDD is the most abundant compound, followed by OCDF and HpCDD, which accorded with the typical PCDD/Fs pattern in Chinese aquatic environment (Martens et al., 2000). Chinese technical pentachlorophenol was found responsible for this contamination pattern because sodium pentachlorophenate has been sprayed for decades to control the spreading of snailborne schistosomiasis in many lake areas in the south of China (Zheng et al., 1997). Further investigation should be done because the data is far from enough to make an exact conclusion.

\subsection{Correlation between indicator PCBs and total PCBs level}

The indicator PCBs are predominantly present in most PCB-mixtures and in environmental samples. Moreover, those PCBs are known to be persistent in the environment and bioaccumulated in the food chain, and are assumed to be a suitable representative for all PCBs (McFarland and Clark, 1989; Kim et al., 2004).
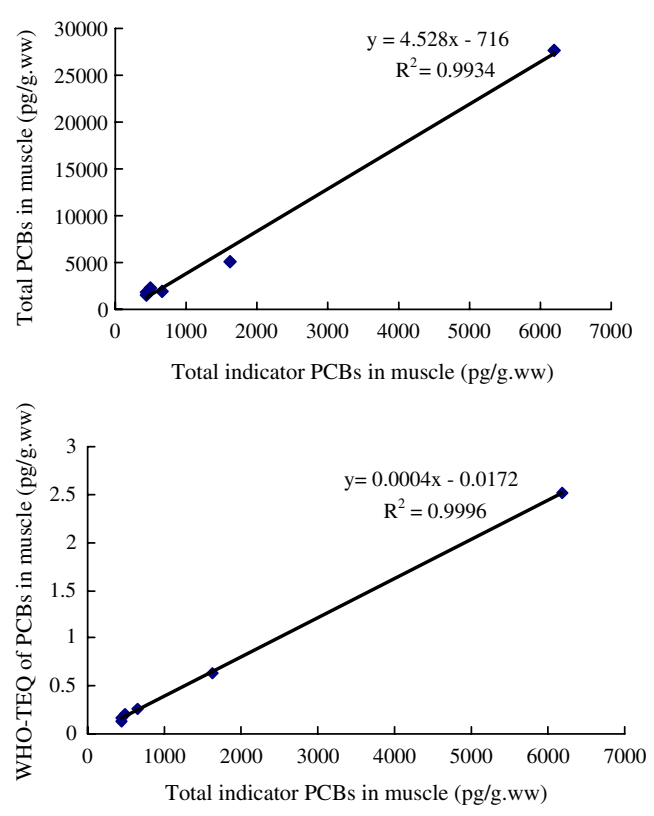

Fig. 6. Relationships between total indicator PCBs and total PCBs or WHO-TEQ of PCBs in sediments and muscles of aquatic organisms of the Taihu Lake. All correlations are significant at $95 \%$ level. 
At present, the indicator PCBs are routinely determined in many environmental monitoring programs and for regulatory purposes. The indicator PCBs are also adopted for regulatory limit in seafood in China. Strong correlations between the indicator PCBs and total PCBs or WHO-TEQ of PCBs in sediments and muscles were found in this study (Fig. 6). The result suggests that it is quite credible to assess all PCBs level in sediment and muscle samples in Taihu Lake based on indicator PCBs. Since the indicator PCBs are the dominant congeners in most of environmental samples, they can be easily detected by some simpler and more economic instruments such as GC-ECD or GC/LRMS. This is more practical to be a routine monitoring way especially for foodstuffs. But another study of us found that the correlation between the indicator PCBs and PCBs based WHO-TEQ was not reliable for sediments in Haihe River (not published). So it should be prudent to assess risk based on this relationship and HRGC/HRMS should be used for check.

\section{Acknowledgments}

This work is a part of project granted by Hi-tech Research and Development Program of China (the grant no. 2002AA601011) and also supported by National Basic Research Program of China (the grant no. 2003CB415001).

\section{References}

Aries, E., Anderson, D.R., Ordsmith, N., Hall, K., Fisher, R., 2004. Development and validation of a method for analysis of "dioxin-like" PCBs in environmental samples from the steel industry. Chemosphere 54, 23-31.

Chen, J.S., Gao, X.M., Qi, M., Blunt, J., 1999. The contents of polychlorinated biphenyl in river sediments in eastern China. Acta Scientiae Circumstantiae (Ch.) 19, 614-618.

Dai, X.L., Sun, C., 2001. The characteristic of heavy metals distribution and pollution in sediment from Lake Taihu. Shanghai Environ. Sci. (Ch.) 20, 71-74.

Feng, K., Yu, B.Y., Ge, D.M., Wong, M.H., Wang, X.C., Cao, Z.H., 2003. Organo-chlorine pesticide (DDT and $\mathrm{HCH}$ ) residues in the Taihu Lake Region and its movement in soilwater system I. Field survey of DDT and $\mathrm{HCH}$ residues in ecosystem of the region. Chemosphere 50, 683687.

Japanese EPA, 1999. Regarding the results of the urgent simultaneous nationwide survey of dioxins (conducted in 1998).

Kim, M., Kim, S., Yun, S., Lee, M., Cho, B., Park, J., Son, S., Kim, O., 2004. Comparison of seven indicator PCBs and three coplanar PCBs in beef, pork, and chicken fat. Chemosphere 54, 1533-1538.

Long, E.R., Macdonald, D.D., Smith, S.L., Calder, F.D., 1995. Incidence of adverse biological effects with ranges of chemical concentrations marine and estuarine sediments. Environ. Manage. 19, 81-97.

Martens, D., Zhang, A., Jiang, X., Chen, J., Gawlik, B.M., Henkelmann, B., Schramm, K.W., Kettrup, A., 2000. Polychlorinated dibenzo- $p$-dioxins and dibenzo- $p$-furans, pentachlorophenol, pentachloroanisole and hexachlorobenzene in sediments of the Yangtze River and the Liao-He River in China. Organohalogen Compd. 46, 431-434.

McFarland, V.A., Clark, J.U., 1989. Environmental occurrence, abundance and potential toxicity of polychlorinated biphenyl congeners: consideration for a congener-specific analysis. Environ. Health Perspect. 81, 225-239.

Qiu, X., Zhu, T., Li, J., Pan, H., Li, Q., Miao, G., Gong, J., 2004. Organochlorine pesticides in the air around the Taihu Lake, China. Environ. Sci. Technol. 38, 1368-1374.

Van Bavel, B., 2003. Final Report Eight Round of the International Intercalibration Study. Workgroup International Intercalibration Studies, Sweden.

Van den Berg, M., Birnbaum, L., Bosveld, A.T.C., Brunström, B., Cook, P., Feeley, M., Giesy, J.P., Hanberg, A., Hasgawa, R., Kennedy, S.W., Kubiak, T., Larsen, J.C., Van Leeuwen, F.X.R., Liem, A.K.D., Nolt, C., Peterson, R.E., Poellinger, L., Safe, S., Schrenk, D., Tillitt, D., Tysklind, M., Younes, M., Wærn, F., Zacharewski, T., 1998. Toxic equivalency factors (TEFs) for PCBs, PCDDs, PCDFs for humans and wildlife. Environ. Health Perspect. 106, 775-792.

Wang, W., Wang, C.X., Wu, W.Z., Mo, Z., Wang, Z.J., 2003. Persistent organic pollutants in water and surface sediments of Taihu Lake, China and risk assessment. Chemosphere 50, 557-562.

Yuan, X.Y., Chen, J., Tao, Y.X., Ji, J.F., Xu, N.Z., 2002. Spatial characteristics and environmental implication of nitrogen and phosphorus from bottom sediments in northern Taihu Lake. Geochimica (Ch.) 31, 321-328.

Yuan, X.Y., Wang, Y., Sun, C., Xu, N.Z., Chen, J., 2004. Characteristics and effects of polychlorinated biphenyls in sediments from Taihu Lake. Resour. Environ. Yangtze Basin 13, 272-276.

Zhang, Y.L., Qin, B.Q., 2001a. Study on the evolvement of water environment in Taihu Lake. Trans. Oceanol. Limol. (Ch.) 2, 8-15.

Zhang, Y.P., Qu, W.C., 2001b. Determination of heavy metal contents in the sediments from Taihu Lake and its environmental significance. Rock Min. Anal. (Ch.) 20, 34 36.

Zheng, M.H., Bao, Z.C., Wang, K.O., Yang, H., Xu, X.B., 1997. Polychlorinated dibenzo-p-dioxins and dibenzofurans in lake sediments from Chinese schistosomiasis areas. Bull. Environ. Contam. Toxicol. 59, 653-656.

Zou, H.X., Sheng, G.Y., Sun, C., Xu, O.Y., 1996. Distribution of organic contaminants in Lake Taihu. Water Res. 30, 2003-2008. 